\title{
APPLICATION OF LEASING AS A TOOL FOR MANAGING SOCIO-ECONOMIC ENTERPRISE DEVELOPMENT
}

\section{ЗАСТОСУВАННЯ ЛІЗИНГУ ЯК ІНСТРУМЕНТУ УПРАВЛІННЯ СОЦІАЛЬНО-ЕКОНОМІЧНИМ РОЗВИТКОМ ПІДПРИЕМСТВА}

\section{Zaluckyj Volodymyr ${ }^{1}$ Bets Mariana $^{2}$}

DOI: https://doi.org/10.30525/978-9934-571-78-7_7

Abstract. Socio-economic development (SED) of an industrial enterprise doesn't belong to natural phenomena. Its nature and dynamics depend on the decisions of economic entities. For specific parameters values of SED of the enterprise, it needs to be managed. Management of SED of enterprise takes place at strategic and tactical levels. At the strategic level of management of enterprise SED, there is the choice and implementation of the strategy of providing enterprise SED. It provides for a consistent realization of stages as follows: analysis of information to identify the actual level of enterprise SED; identification of expected values of SED indicators; identification of the factors influencing the enterprise SED in terms of leasing; the choice of methods of influence on the factors that affect the enterprise SED in terms of leasing; choice and implementation of a strategy for achieving the expected values of the SED indicators in terms of leasing; performance of the control over the state of strategy implementation; regulation of strategy implementation. Implementation of this strategy is aimed at achieving the expected values of SED in the long run on the conditions of use of the equipment obtained by the enterprise on leasing terms.

\footnotetext{
${ }^{1}$ Candidate of Economic Sciences, Associate Professor,

Senior Lecturer at Department of Business Economics and Investments,

Lviv Polytechnic National University, Ukraine

${ }^{2}$ Candidate of Economic Sciences, Associate Professor,

Senior Lecturer at Department of Entrepreneurship and Environmental Expertize of Goods,

Lviv Polytechnic National University, Ukraine
} 


\section{1. Ветуп}

В умовах загострення конкуренції на ринку промислової продукції забезпечення СЕР промислових підприємств потребує зниження енергомісткості виробництва, підвищення рівня його екологічності, досягнення вищого рівня якості продукції тощо. Одним із перспективних методів виконання цих завдань є лізинг. Незважаючи на те, що лізинг має давню історію, проблематичність його застосування в Україні полягає у тому, що в умовах, які склались, керівники вітчизняних підприємств не можуть скористатись набутим світовим досвідом у використанні лізингу для досягнення очікуваних значень СЕР без реалізації певних організаційних рішень, які враховують положення чинних правових актів, а також адаптують стратегію і тактику підприємств до тенденцій і кон'юнктури розвитку промисловості в Україні. Використання підприємством лізингу в якості методу досягнення очікуваних значень показників СЕР супроводжується використанням таких методів як інтенсифікація виробництва, впровадження інноваційних технологій тощо. Лізинг систематизує різні методи впливу на досягнення очікуваних значень показників СЕР підприємства. Наявність зв'язків між лізингом та іншими методами забезпечення СЕР підприємств вказує на необхідність постійного моніторингу наслідків застосування конкретних методів i факторів, які впливають на значення показників СЕР. Ігнорування необхідності проведення такого моніторингу може стати причиною дисбалансів у виникненні грошових потоків, що неминуче негативно позначиться на фінансовій стійкості підприємства, його можливостях щодо здійснення інвестицій і залучення кредитних ресурсів тощо.

\section{2. Стратегічне забезпечення соціально-економічного розвитку підприємства на засадах лізингу}

Рівень СЕР підприємств постійно змінюється під впливом факторів внутрішнього і зовнішнього середовищ. Підприємства, на яких реалізовуються активні стратегії розвитку, що передбачають посилення конкурентної позиції, збільшення обсягу прибутку, заволодіння привабливими контрактами тощо, перманентно перебувають у стані акумулювання та оброблення інформації на предмет можливостей оптимізації витрат щодо досягнення очікуваних значень показників СЕР у заплановані терміни. Вибір і реалізація стратегії забезпечення СЕР підприємства на засадах використання лізингу передбачає низку етапів, що виділені на рис. 1. 


\section{Chapter «Economic sciences»}

Аналіз інформації на предмет виявлення фактичного рівня СЕР підприємства

Встановлення очікуваних значень показників СЕР

Виявлення характеру факторів, які впливають на СЕР підприємства в умовах використання лізингу

Вибір методів впливу на фактори, які впливають на СЕР підприємства в умовах використання лізингу

Вибір і реалізація стратегії досягнення очікуваних значень показників СЕР в умовах використання лізингу

Виконання функції контролю за станом реалізації стратегії

Регулювання реалізації стратегії

\section{Рис. 1. Етапи вибору і реалізації стратегії забезпечення СЕР підприємства на засадах використання лізингу}

Аналіз управлінської інформації аналітики підприємств здійснюють в ручному та автоматизованому режимах. Обрання способу обробки інформації залежить від характеру даних, рівня розвитку системи інформаційного забезпечення, а також від цілей обробки даних. У наведеній технології акумулювання та обробка інформації здійснюється задля обгрунтованого встановлення очікуваних значень показників СЕР. Як видно з рис. 2, при встановленні значень показників СЕР підприємств можуть використовуватись кілька орієнтирів. Найбільш поширеними з них є: значення показників минулих періодів, значення показників підприємств у галузі, значення показників провідних конкурентів, значення показників, встановлені на основі прогнозування попиту і пропозиції у галузі. Для встановлення очікуваних значень показників СЕР може обиратись один або більше орієнтирів. Цей вибір залежить від можливостей організації, їі місця на ринку, обраної стратегії розвитку тощо. Під час встановлення 
допустимих значень показників СЕР підприємства, а також під час формування рішень щодо їх досягнення одним 3 ключових завдань $\epsilon$ встановити фактори, які впливають на значення показників СЕР підприємства, а також виявити їх характер. Виконання цього завдання вимагає постійного розширення і комбінування джерел отримання інформації про ці фактори.

На рис. 3 наведено перелік найбільш використовуваних керівниками підприємств джерел отримання інформації про характер факторів, які впливають на значення показників їх СЕР.

На підставі отримання обробки інформації про перелік і характер виявлених факторів керівники підприємства здійснюють вибір методів впливу на них з метою стимулювання дії факторів, які підвищують значення показників СЕР підприємства, а також обмеження дії факторів, які знижують досягнутий підприємством рівень СЕР. На рис. 4 наведено класифікацію цих методів. При обранні і використанні цих методів доцільно враховувати взаємозв'язки між факторами, а також те, що в їх переліку можуть виявитись чинники, до яких підприємство змушене пристосовуватись.

Для досягнення раціональності зусиль керівників і аналітиків підприємств щодо оптимізування показників СЕР доцільно формувати автоматизовану системну базу даних про фактори і методи впливу на них, що суттєво спрощуватиме і прискорюватиме процес формування управлінських рішень.

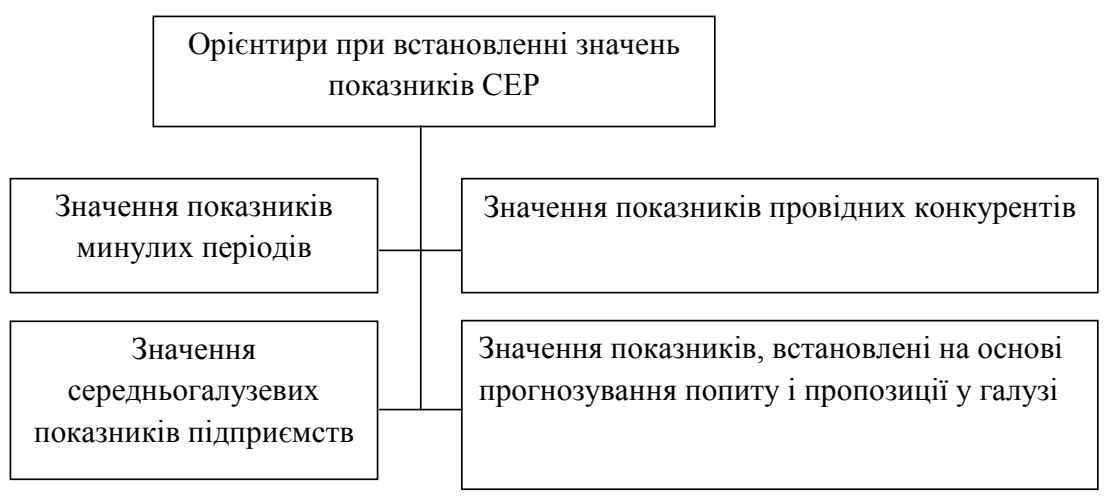

Рис. 2. Оріснтири при встановленні значень показників СЕР 
Джерела отримання інформації

Промисловий шпіонаж

Результати аналізу публічної інформації

Управлінська та статистична звітність

Поточна виробничо-управлінська документація

Установчі документи і положення про підрозділи

Концепції і програми розвитку

Особові справи підлеглих тощо

Рис. 3. Джерела отримання інформації про характер факторів, які впливають на СЕР підприсмства

Класифікація методів впливу на фактори

За характером: методи прямого впливу; методи опосередкованого впливу

За результативністю: методи, які забезпечили очікуваний результат; методи, які не забезпечили очікуваного результату

За рівнем складності: методи, які застосовуються індивідуально, незалежно один від одного; методи, які застосовуються у комбінації один з одним

Рис. 4. Класифікація методів впливу на фактори, від яких залежать значення показників СЕР підприємства 


\section{Zaluckyj Volodymyr, Bets Mariana}

В основу організації баз даних покладено принцип єдності. На всіх етапах життєвого циклу баз даних складається 3 двох компонентів - структури та даних. На різних рівнях опису баз даних, iii структура зображується: на інфологічному та датологічному рівнях і вона може бути ієрархічною, мережевою, реляційною, об'єктно-орієтова ᄀною, об’єктно-реляційною, багатовимірною, змішаною; на фізичному рівні - структурою файлів даних і допоміжних файлів. Процес побудови автоматизованої системи баз даних передбачає: формування моделі даних, застосування стандартної схеми SAIF; вироблення логічної схеми конструкції побудованої моделі даних, найчастіше реляційної; фізичне конструювання моделі системи класифікації баз даних [1]. Найважливішим аспектом автоматизації системних баз даних є його апаратне забезпечення, яке включає: бази даних; системне програмне забезпечення; програмне забезпечення роботи 3 даними; спеціальне програмне забезпечення для виконання конкретних виробничо-господарських та управлінських операцій; інтерфейс користувача. Результативність роботи із створення функціонального апаратного забезпечення автоматизації системних баз даних залежить від адекватності розуміння проектувальниками цілей використання інформаційної системи управління підприємством, від рівня наближення проекту побудованої системи баз даних до потреб користувачів. Обрання конкретних способів пливу на виявлені фактори задля досягнення очікуваних значень показників СЕР підприємства $є$ ознакою процесу формування певної стратегії управління. На рис. 5 наведено найбільш поширені у промисловості види стратегій.

3 теорії стратегічного управління загальновідомим $є$ те, що обрання i застосування певної стратегії підприємством відбувається за технологією,

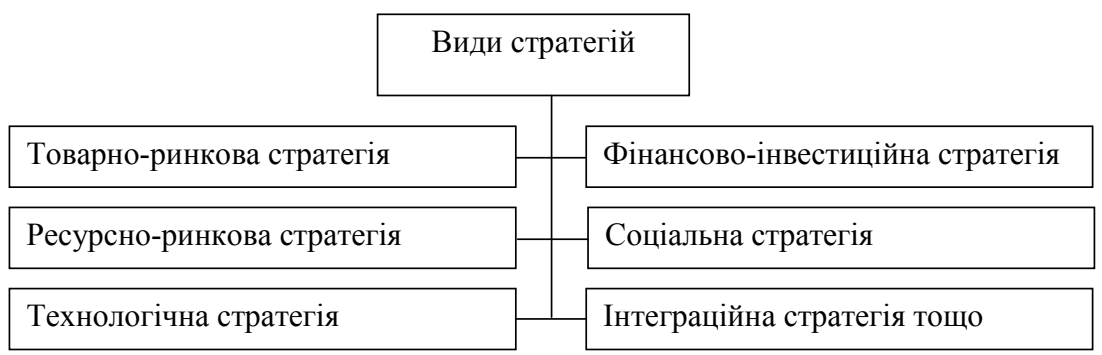

Рис. 5. Види стратегій 


\section{Chapter «Economic sciences»}

яка наведена на рис. 6. Дотримання цієї технології керівниками підприємств не гарантує досягнення очікуваного рівня СЕР в заплановані терміни, проте суттєво знижує рівні різноманітних управлінських ризиків.

Важливим аспектом технології покращання СЕР підприємства на засадах використання лізингу є ефективність поточного і заключного контролю за: діяльністю працівників, які реалізовують завдання обраної стратегії; значеннями показників СЕР і факторами, які на них впливають; а також результативністю застосування методів впливу на фактори, що діють на значення показників СЕР підприємства. Працівники керуючої системи управління контролюють діяльність працівників керованої системи управління, зміну показників СЕР підприємства, а також результативність застосування методів впливу на фактори, що впливають на значення показників СЕР підприємства.

На рис. 7 наведено узагальнену схема виконання функції контролювання за реалізацією обраної стратегії.

Функція контролювання уможливлює зворотну комунікацію для керуючої підсистеми управління про хід виконання його рішень суб'єктами керованої підсистеми.

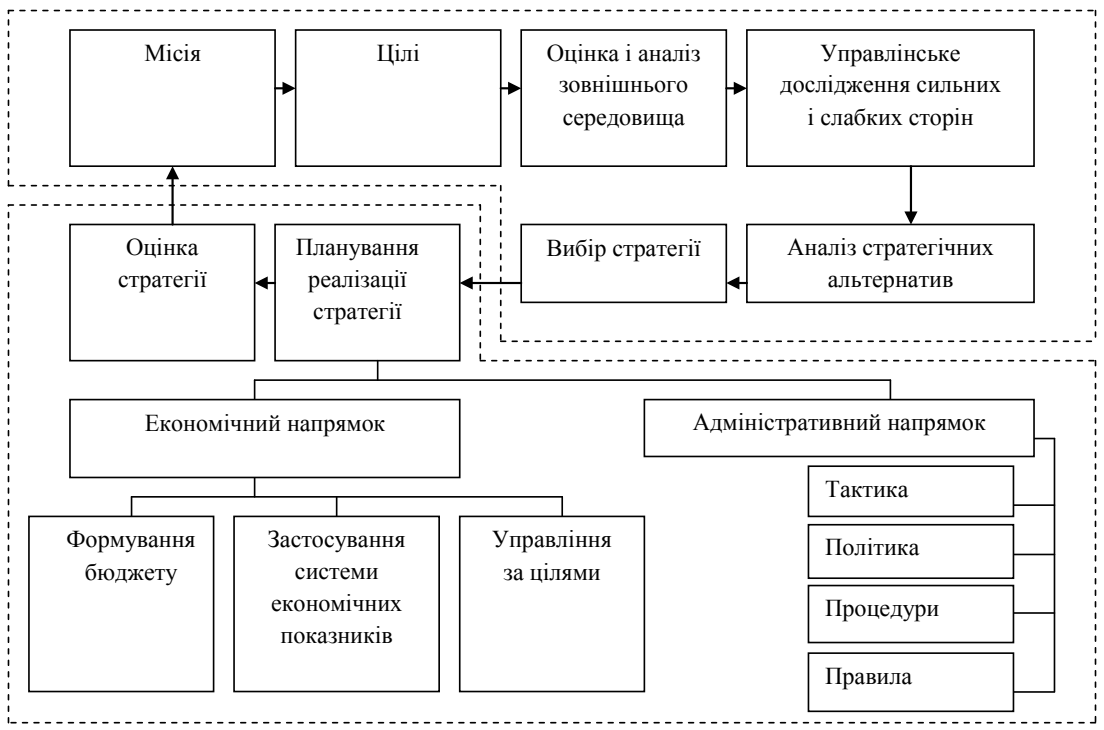

Рис. 6. Процес стратегічного планування [2] 


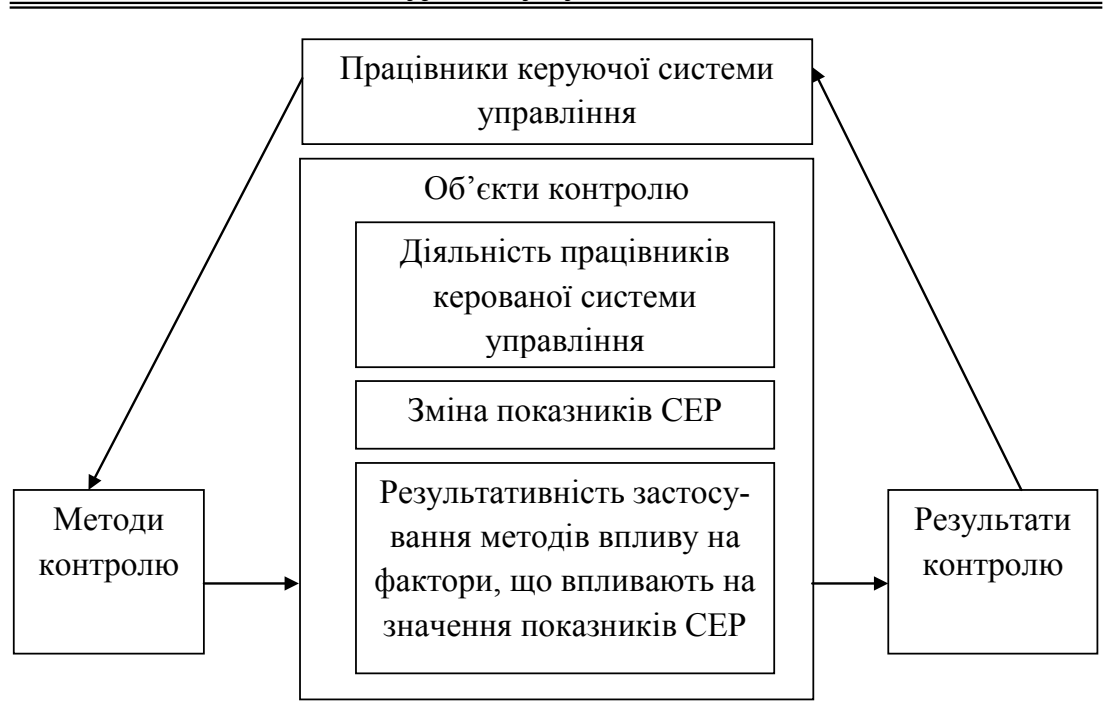

Рис. 7. Виконання функції контролювання за реалізацією обраної стратегії забезпечення СЕР підприємства

Якщо справи йдуть добре, тоді контроль дає змогу підтримувати хід справ; якщо результати гірші від очікуваних, тоді контроль допомагає внести необхідні корективи. Під час контролювання реалізації обраної стратегії забезпечення СЕР підприємства слід дотримуватися кількох правил: 1) встановлювати жорсткі, але реальні для досягнення критерії й такі, що об'єктивно відображають результати СЕР. Чіткі критерії часто формують мотивацію вже тим, що працівники точно знають, чого від них хочуть керівники. Встановлювати двостороннє спілкування між менеджерами і підлеглими. Уникати прискіпливого і прихованого контролю; 2) менеджерам не слід перевантажувати своїх підлеглих численними формами контролю. Крім того, контроль має бути всеохоплюючим, операційним, оперативним, зосередженим на результатах, простим, безперервним [3].

За результатами виконання функції контролю може виникати необхідність регулювати обрану стратегію досягнення значень показників СЕР підприємства на засадах лізингу. Проведений аналіз показав, що усі без винятку регулюючі рішення можна віднести до обмежувальних або стимулюючих. На рис. 8 наведено напрями застосування методів регулювання. 
Стимулювання: премії; подяки; бонуси; знижки; контракти на співпрацю тощо
Обмеження: догани; штрафи; позови; пониження по посаді тощо

\section{Рис. 8. Напрями застосування методів регулювання}

У науковій літературі приділено достатньо багато уваги методичному інструментарію застосування регулюючих рішень у вищенаведених стимулюючих і обмежувальних напрямах, проте особливостям ïх застосування в умовах лізингу як способу стимулювання соціально-економічного розвитку вони майже нерозглянуті. Найбільш поширеним об'єктом регулювання лізингових відносин $є$ умови контрактів щодо надання майна у лізинг. Отримавши право власності на об'єкт лізингу, лізингова компанія укладає договір лізингу з лізингоодержувачем, згідно з яким до лізингоодержувача переходить виняткове право користування об'єктом лізингу на умовах строковості та платності [4]. Саме ці параметри є основним предметом регулювання у лізинговому договорі.

\section{3. Тактичне забезпечення соціально-економічного розвитку підприємства на засадах лізингу}

Лізинг тісно пов'язаний із іншими тактичними інструментами забезпечення СЕР підприємства. Його застосування так чи інакше супроводжується інтенсифікацією виробництва, впровадженням інноваційних технологій тощо. Дослідження показали, що лізинг систематизує різні тактичні інструменти досягнення очікуваних значень показників СЕР підприємства. На рис. 9 показано місце лізингу у систематизації тактичних інструментів досягнення очікуваних значень показників СЕР підприємства.

Як видно з наведеного рисунку, суб'єкти управління СЕР підприємства встановлюють цілі СЕР і приймають рішення щодо вироблення тактики впливу на об'єкт управління (СЕР). Якщо серед обраних тактичних інструментів досягнення очікуваних значень СЕР підприємства має місце оновлення застарілого обладнання і впровадження 


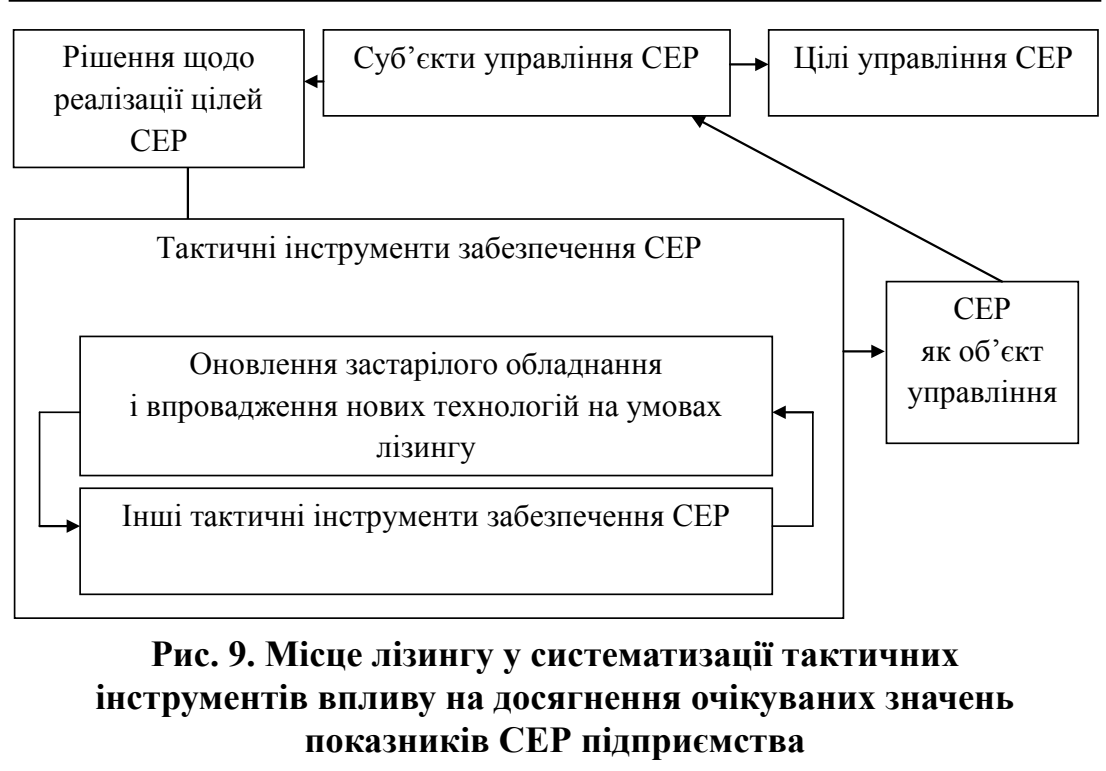

нових технологій на умовах лізингу, то цей інструмент супроводжується застосування інших тактичних інструментів впливу на СЕР. Між лізингом, та іншими інструментами впливу на СЕР підприємства має місце взаємозв'язок. Це вказує на необхідність постійного моніторингу наслідків застосування конкретних інструментів і факторів, які впливають на значення показників СЕР.

3 метою обгрунтування вищенаведеної позиції і конкретизації зв'язків лізингу із іншими інструментами досягнення очікуваних значень показників СЕР розглянемо ці зв'язки. Як видно з рис. 10, у результаті застосування лізингу може мати місце інтенсифікація виробництва.

Логіка виникнення причинно-наслідкових зв'язків між цими тактичними інструментами полягає у наступному: метою оновлення застарілого обладнання за допомогою лізингу, як правило, є підвищення якості або зниження собівартості продукції, а також розширення номенклатури і асортименту продукції. В результаті застосування лізингу задля досягнення цих цілей попит на продукцію може зрости, знизитись або залишитись незмінним. Якщо попит зростає, то це є підставою для інтенсифікації виробництва. Застосування методу інтенсифікації неминуче позначиться на показниках СЕР підприємства, зокрема на обсязі 


\section{Chapter «Economic sciences»}

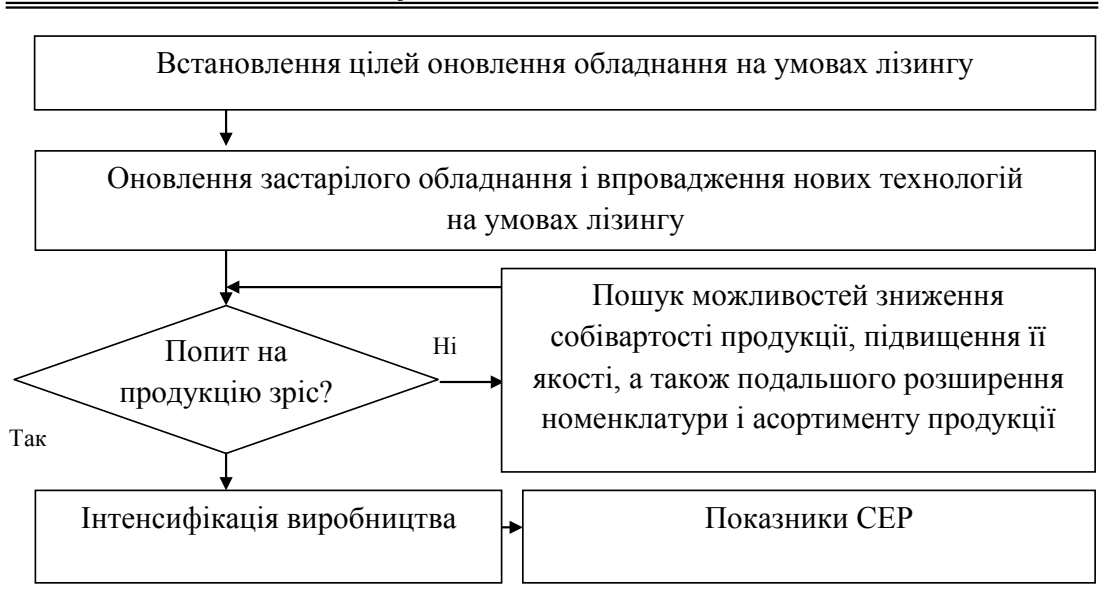

\section{Рис. 10. Інтенсифікація виробництва як результат застосування лізингу в якості тактичного інструменту забезпечення СЕР підприсмства}

виробництва, оборотності оборотних засобів, прибутковості власного капіталу тощо. Якщо ж у результаті застосування лізингу попит на продукцію не зріс, то це викликає необхідність пошуку можливостей зниження собівартості продукції, підвищення іiї якості, а також подальшого розширення номенклатури та асортименту продукції іншими методами. У разі коли вони дають бажаний результат - зростання попиту, то наслідком цього є інтенсифікація виробництва.

Використання лізингу в якості тактичного інструменту забезпечення СЕР підприємств часто супроводжується організаційними змінами, зокрема реорганізаціями використовуваних організаційних структур управління. На рис. 11 наведено етапи процесу аналізування організаційної структури управління.

Враховуючи те, що отримання підприємством нового обладнання на умовах лізингу супроводжується виникненням фінансових, технологічних, технічних та інших підприємницьких ризиків, то очевидно, що об'єктивною необхідністю є створення належних умов для управління процесом укладання лізингової угоди, і що ще важливіше управління процесом іiі реалізації. Створення цих умов вимагає дослідження наявної організаційної структури управління на предмет: наявності підрозділів і посад, на які доцільно покласти виконання функції управ- 
Аналізування організаційної структури на предмет: наявності підрозділів і посад, на які доцільно покласти виконання функції управління процесом укладання і виконання договорів лізингу; завантаженості підрозділів і посадових осіб, на які можна було б покласти функцію управління процесом укладання і виконання договорів лізингу; фаховості суб'єктів, на яких доцільно покласти виконання функції управління процесом укладання і виконання договорів лізингу.

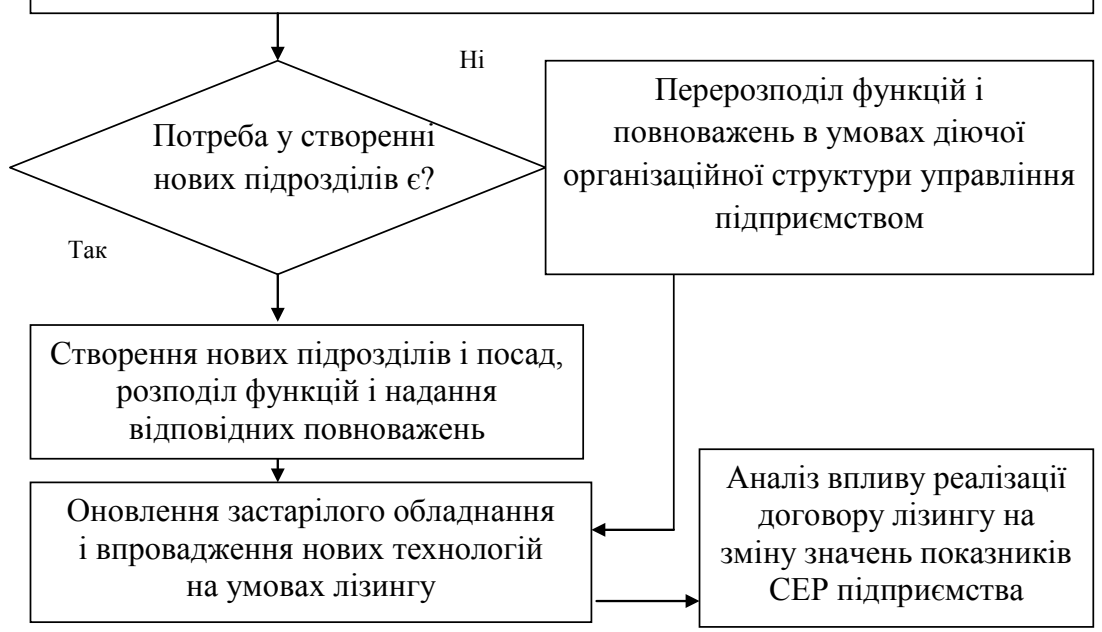

\section{Рис. 11. Процес аналізування організаційної структури управління}

ління процесом укладання і виконання договорів лізингу; завантаженості підрозділів і посадових осіб, на які можна було б покласти функцію управління процесом укладання і виконання договорів лізингу; фаховості суб'єктів, на яких доцільно покласти виконання функції управління процесом укладання і виконання договорів лізингу.

Якщо в результаті аналізування діючої організаційної структури управління виявлено потребу у створенні нових підрозділів, то це передбачає реалізацію відповідних організаційних змін, після яких відбуватиметься оновлення застарілого обладнання і впровадження нових технологій на умовах лізингу.

Доцільно відзначити, що аналіз використовуваної організаційної структури управління підприємством може показати, що існуюча 


\section{Chapter «Economic sciences»}

структура достатньо розвинута для застосування лізингу як інструменту досягнення очікуваних значень показників СЕР підприємства. В такому випадку керівники підприємства реалізовують організаційні зміни шляхом перерозподілу функцій і повноважень в умовах діючої організаційної структури управління підприємством.

Реалізацію цих організаційних змін і застосування лізингу необхідно завершувати аналізом зміни значень показників СЕР підприємства для виявлення необхідності прийняття відповідних регулюючих рішень.

За даними членів Асоціації «Українське об’єднання лізингодавців» практично усі договори лізингу, які реалізовуються за участю вітчизняних підприємств супроводжуються застосуванням останніми раціоналізації логістики в якості тактичного інструменту забезпечення очікуваних значень показників СЕР. Для цього є об'єктивні підстави, адже під час залучення обладнання на умовах лізингу і під час його використання виникають певні потоки ресурсів, які потребують їхньої оптимізації. На рис. 12 наведено взаємозв'язки між лізингом і раціоналізацією логістичних потоків як методами забезпечення СЕР підприємства.

Як бачимо з рис. 12, прийняття рішення про оновлення підприємством обладнання на умовах лізингу передбачає аналізування раціональності логістичних потоків підприємства. Вихідними положеннями логістичного аналізу є діалектика, комплексність, розвиток, пріоритетність, повнота і достовірність використовуваних баз даних тощо. Методичний інструментарій, що при цьому застосовуються лежить в межах загального техніко-економічного аналізу виробничо-господарської діяльності. Найбільш застосовуваним у логістиці є АВС-аналіз і XYZ-аналіз [5; 6].

ABC-аналіз дозволяє: здійснити декомпозицію напрямків діяльності підприємства; ідентифікувати пріоритетні вектори розвитку; аргументувати найбільш важливі об'єкти вкладення коштів; визначити вузлові, проблемні точки бізнес-процесів; підготувати аналітичні матеріали для формування рішення щодо раціоналізації управління бізнес-процесами.

Своєю чергою, XYZ-аналіз, який використовується під час управління потоками матеріалів. Він передбачає оцінку їх значимості в залежності від частоти споживання. XYZ-аналіз дозволяє встановити, на які ресурси є постійний і стабільний попит, які з ресурсів характеризуються сезонним, або випадковим попитом. Тому в межах кож- 


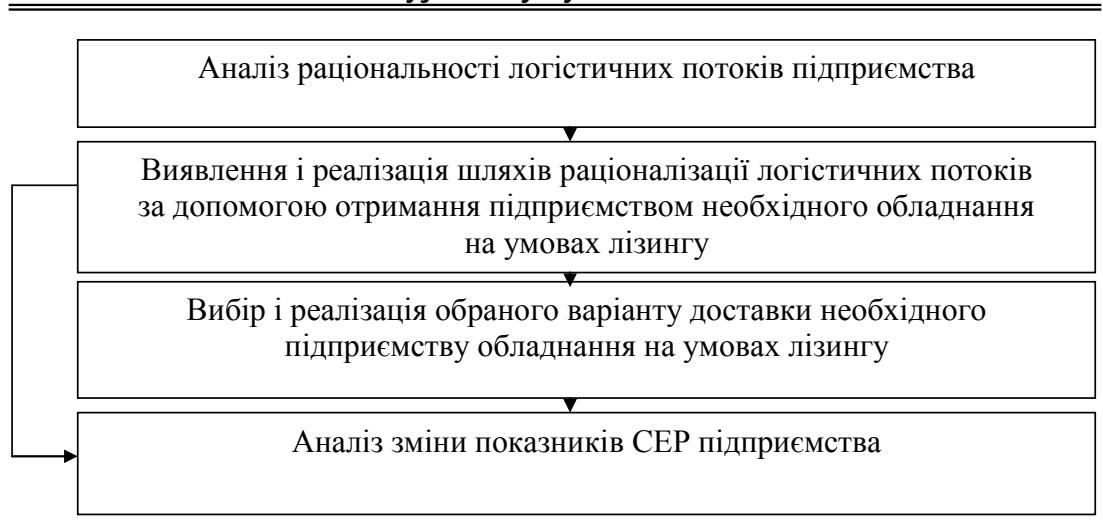

\section{Рис. 12. Взаємозв'язки між лізингом і раціоналізацією логістичних потоків як тактичними інструментами забезпечення СЕР підприємства}

ного із класів ресурсів XYZ-аналіз уможливлює диференціацію як за рівнем прогнозованості їх витрат так і стабільності їх надходження чи вибуття зі складу підприємства. Для такої класифікації використовуються символи X, Y, Z [5]. Очевидно, що під час управління виконанням лізингового договору більш прийнятним є АBC-аналіз. Результатом його застосування є виявлення і реалізація шляхів раціоналізації логістичних потоків за допомогою отримання підприємством необхідного обладнання на умовах лізингу. Раціоналізація може бути досягнута шляхом набуття лізингоотримувачем членства у виробничо-господарських об'єднаннях, в структурі яких є лізингові компанії, формування певного клірингового союзу, який дозволить здійснити взаємозалік платежів, або використати факторингову угоду в якості плати за послуги транспортування обладнання, що передається лізингодавцем у користування лізингоотримувачу, обумовлення договором лізингу певних преференцій у сплаті лізингових платежів за перенесення відповідальності щодо постачання обладнання на лізингоотримувача тощо. Наступним етапом процесу раціоналізації логістичних потоків, які пов'язані із використанням лізингу в якості тактичного інструменту забезпечення СЕР підприємства є вибір і реалізація обраного варіанту доставки необхідного підприємству обладнання на умовах лізингу, а також аналіз зміни показників СЕР підприємства. 


\section{Chapter «Economic sciences»}

Доцільно визнати, що далеко не завжди лізинг передбачає отриманням підприємством інноваційних технологій, проте критерії інноваційності технологій і обладнання, що їх супроводжує достатньо невизначені. 3 одного боку, інноваційна технологія та інноваційне обладнання характеризуються абсолютною новизною. Для того, щоб їх назвати інноваційними вони повинні характеризуватись відсутністю будь-яких аналогів і досвіду у їхньому практичному використанні. Проте, з іншого боку, для конкретного підприємства і навіть галузі конкретної країни певна технологія і обладнання, які добре апробовані за кордоном можуть бути абсолютно невідомими і їхнє застосування $€$ інновацією, яка здатна суттєво змінити рівень СЕР. Враховуючи це, в умовах економіки України, де знос основних виробничих фондів на більшості промислових підприємств є критичним до інноваційних технологій та інноваційного обладнання є сенс відносити ті об'єкти, технологічні, екологічні та інші параметри яких суттєво відрізняються від тих, технологій та обладнання, які на сьогодні використовуються підприємствами і потребують заміни.

На рис. 13 показано місце лізингу у впровадженні інноваційних технологій під час забезпечення СЕР підприємства.

Застосуванню інноваційних технологій на підприємстві передує вивчення попиту споживачів продукції на характер інновацій. Результатом цього дослідження має бути висновок проте, які саме технології потрібні підприємству. Загальновідомо, що в технологічному ланцюгу виробництва продукції рівень складності технологій може суттєво варіюватись. Цей рівень обумовлює прийняття керівниками підприємства рішення про створення необхідної інноваційної технології власними силами або про їхнє залучення на умовах лізингу. Якщо наявний потенціал підприємства недостатній для створення інноваційної технології власними силами, тоді керівники підприємства обирають лізинг в якості тактичного інструменту оновлення виробничого обладнання. В результаті його застосування відбувається очікувана зміна показників СЕР. Для отримання запланованих соціально-економічних зрушень не завжди достатнім $є$ оновити обладнання і технології, змінити організаційну структуру і реалізувати рішення логістичного характеру. Часто зміни лінійно залежать від наявності дієвих стимулів для суб'єктів управління в організації, зокрема для підвищення їхньої продуктивності праці. На рис. 14 наведено графічну модель впровад- 
Вивчення попиту споживачів продукції на характер інновацій

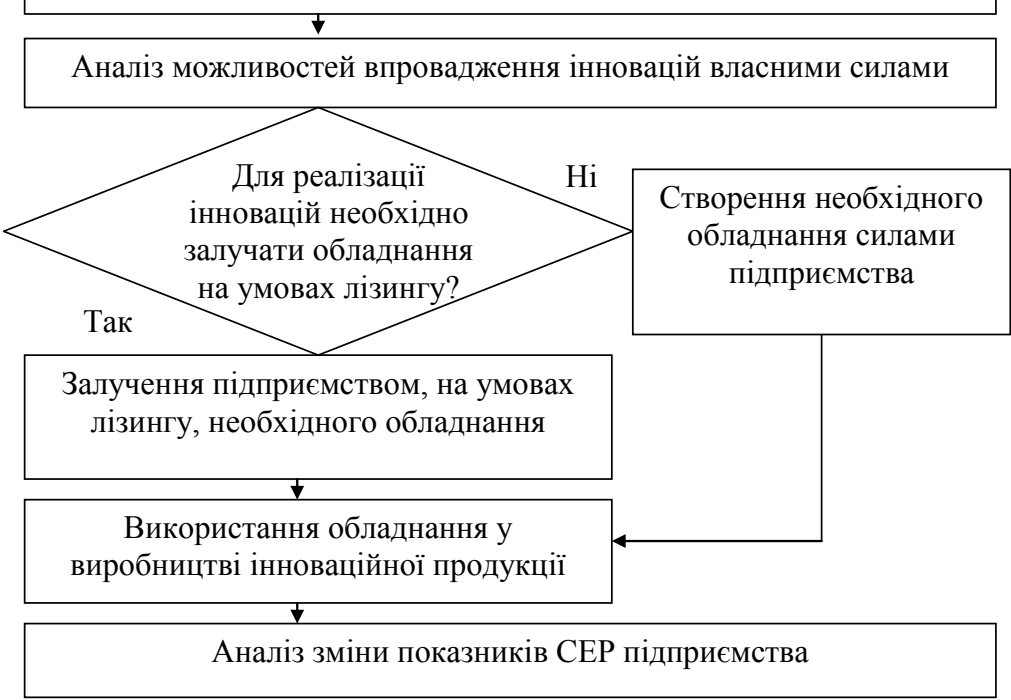

\section{Рис. 13. Місце лізингу у впровадженні інноваційних технологій під час забезпечення СЕР підприємства}

ження стимулів для підвищення продуктивності праці в умовах використання лізингу для забезпечення СЕР підприємства.

Як бачимо, в основі побудованої графічної моделі лежить порівняння зміни рівня продуктивності праці суб’єктів управління, а також зміни кількості бракованої продукції підприємства до і після оновлення застарілого обладнання і впровадження нових технологій на умовах лізингу. Якщо за результатами аналізу рівень продуктивності праці зріс, а частка бракованої продукції підприємства знизилась або залишилась на попередньому рівні, то це засвідчує позитивний вплив лізингу на зміну показників СЕР підприємства.

Якщо ж значення зазначених показників змінилось у протилежному напрямку, то це вимагає дослідження причин виникнення негативної зміни і застосування методів впливу на підлеглих з метою покращання значення вказаних показників у майбутньому. Керівники промислових підприємств стверджують, що аналізування зміни значень показ- 


\section{Chapter «Economic sciences»}

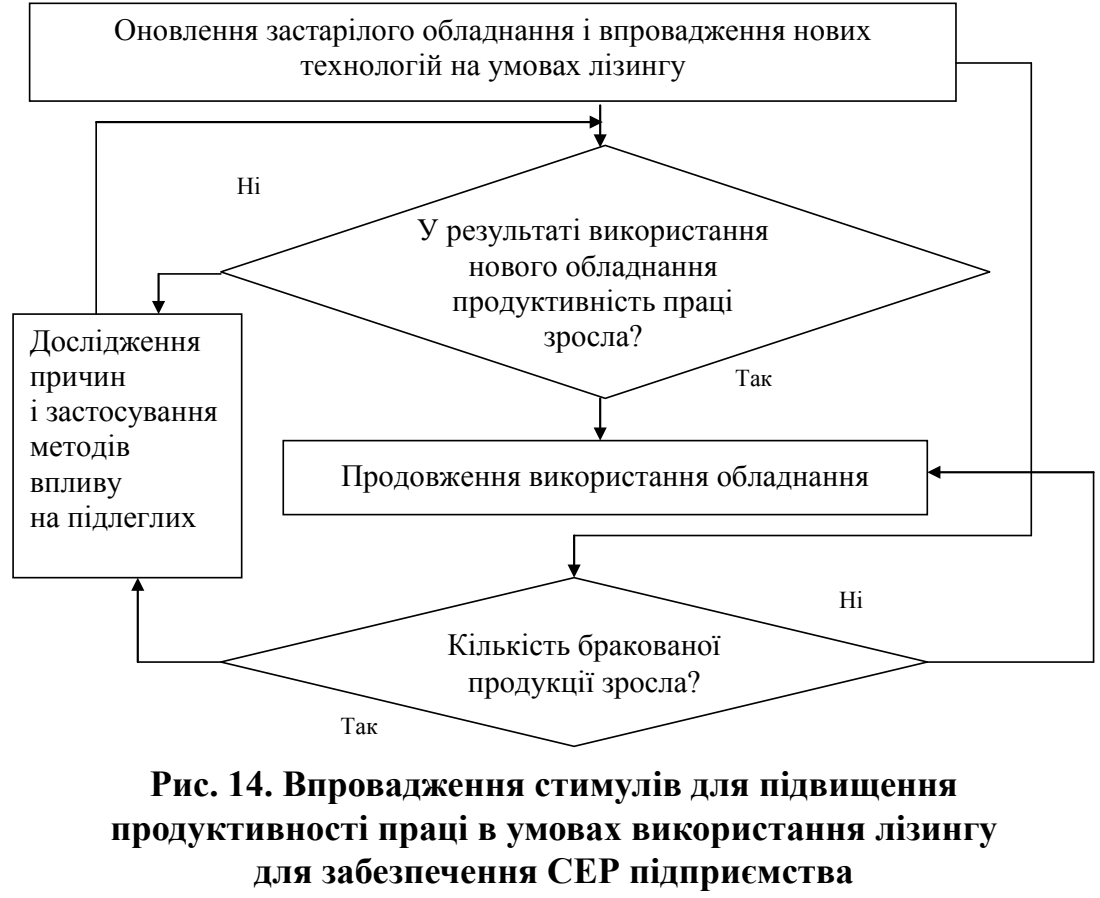

ників СЕР підприємства не $є$ причиною для застосування стимулів до суб'єктів управління з метою підвищення їхньої продуктивності праці, а також якості виконання тих чи інших виробничих операцій, їх доцільно розцінювати як орієнтири для зміни тих чи інших методів впливу на підлеглих у часі і просторі.

Одним із тактичних інструментів забезпечення СЕР підприємства є ліквідація або передача у тимчасове користування бізнес-партнерам неприбуткових активів. Цей метод також тісно пов'язаний з лізингом. На рис. 15 показано вплив лізингу на структуру активів підприємства та інші показники СЕР.

Отримавши нове обладнання на умовах лізингу підприємство одержує новий орієнтир для аналізування завантаженості виробничих потужностей і прибутковості використовуваного обладнання та інших активів. Якщо за результатами аналізу виявлясться, що частина активів не бере участі у виробничо-господарських процесах 
Аналіз структури і прибутковості активів підприємства до залучення обладнання на умовах лізингу

Аналіз структури і прибутковості активів підприємства після залучення обладнання дання на умовах лізингу

Виявлення активів, які доцільно продати або передати у користування інших суб'єктам господарювання

Реалізація або передача у тимчасове користування активів іншим суб'єктам господарювання

Аналіз новоствореної структури активів підприємства і їхнього впливу на показники СЕР підприємства

\section{Рис. 15. Етапи вплив лізингу на структуру активів підприсмства та інші показники СЕР}

і не приносить очікуваного прибутку, то це $є$ підставою для їхньої ліквідації або передачі у користування іншим організаціям. За даними Асоціації технологів-машинобудівників України на сьогодні в середньому по Україні 30\% основних виробничих фондів підприємств не приносять очікуваного прибутку, ще $15 \%$ активів забезпечують їхнім власникам прибуток за рахунок здачі їх в оренду або передачі на умовах лізингу іншим організаціям. Члени асоціації відзначають також, що значна частина активів підприємств могла б використовуватись набагато раціональніше за умови залучення на підприємства більш сучасних технологій.

\section{4. Висновки}

Розроблена аналітико-декомпозиційна модель соціально-економічного розвитку підприємств основана на системі показників і факторів, які засвідчують наявність або відсутність доцільності зміни пріоритетів СЕР на засадах застосування лізингу, а також технології вироблення і реалізації управлінських рішень щодо застосування лізингу як методу СЕР підприємств. Аналітикам підприємств необхідно практично застосовувати iï, для того щоб об'єктивно встановити досягнений рівень СЕР і обгрунтованість реалізації лізингових проектів. 


\section{Chapter «Economic sciences»}

Запропоновані методичні положення щодо забезпечення СЕР підприємств на засадах лізингу базуються на урахуванні місця лізингу в технологічному процесі виробництва промислової продукції, встановленні зв'язків лізингу, як методу забезпечення соціально-економічного розвитку підприємства, із іншими методами, ідентифікуванні принципів застосування цих методів, а також розкритті сутності прямих i опосередкованих впливів лізингу на показники СЕР підприємств. Використовуючи цю модель, керівники підприємств зможуть раціоналізувати напрями використання фінансових, матеріальних, інформаційних та інших ресурсів під час застосування лізингу як методу забезпечення СЕР підприємств.

\section{Список літератури:}

1. Переоцінка активів [Електронний ресурс]. - Режим доступу: http://www.dtkt.com.ua

2. Кузьмін О.С. Сучасний менеджмент. - Львів: Центр Європи, 1995. - C. 28-31.

3. Новости украинского бизнеса [Електронний ресурс]. - Режим доступу: http://www.vlasnasprava.info

4. Національна служба посередництва i примирення [Електронний pecypc]. - Режим доступу: http://www.nspp.gov.ua

5. Конспект «Логістика» [Електронний ресурс]. - Режим доступу: http://www.refine.org.ua/pageid-4770-8.html

6. Чухрай Н., Патора Р. Інновації та логістика товарів / Національний ун-т «Львівська політехніка»; Громадська вища школа підприємництва та управління в м. Лодзі, Республіка Польща. - Л.: Видавництво Національного ун-ту «Львівська політехніка», 2001. - 262 с.

\section{References:}

1. Pereotsinka aktyviv [Elektronnyy resurs]. - Rezhym dostupu: http://www.dtkt.com.ua

2. Kuzmin O.YE. Suchasnyy menedzhment. - Lviv: Tsentr Yevropy, 1995. - P. 28-31.

3. Novosty ukraynskoho byznesa [Elektronnyy resurs]. - Rezhym dostupu: http://www.vlasnasprava.info

4. Natsional'na sluzhba poserednytstva i prymyrennya [Elektronnyy resurs]. Rezhym dostupu: http://www.nspp.gov.ua

5. Konspekt «Lohistyka» [Elektronnyy resurs]. - Rezhym dostupu: http://www.refine.org.ua/pageid-4770-8.html

6. Chukhray N., Patora R. Innovatsiyi ta lohistyka tovariv / Natsionalnyy un-t «Lvivska politekhnika»; Hromads'ka vyshcha shkola pidpryyemnytstva ta upravlinnya v m. Lodzi, Respublika Pol'shcha. - L.: Vydavnytstvo Natsional'noho un-tu «Lvivska politekhnika», 2001. - $262 \mathrm{~s}$. 